\title{
ANALYSIS OF MULTI-TERMINAL HVDC TRANSMISSION SYSTEM FEEDING VERY WEAK AC NETWORKS
}

\author{
S. Singaravelu ${ }^{1}$, S. Seenivasan ${ }^{2}$ \\ ${ }^{1}$ Professor, Department of Electrical Engineering, Annamalai University, Annamalai Nagar-608002, Tamilnadu, \\ India \\ ${ }^{2}$ Assistant Professor, Department of Electrical Engineering, Annamalai University, Annamalai Nagar-608002, \\ Tamilnadu, India
}

\begin{abstract}
This paper presents a line commutated converter (LCC) based multi-terminal HVDC transmission (MTDC) system feeding very weak AC networks with hybrid reactive power compensators (RPC's) at the inverter AC side. The hybrid compensator is accomplished by the equal mixing of any two of the following compensators: synchronous compensator (SC); static var compensator (SVC); static synchronous compensator (STATCOM). The four-terminal HVDC transmission system model is implemented in the Matlab with the firefly algorithm based optimal proportional integral (PI) controller for rectifiers and inverters control. The transient performances of hybrid RPC's (SC+SVC, SVC+STATCOM and SC+STATCOM) are studied under various fault conditions and the results are compared with the performance of the SC, SVC and STATCOM to focus the high quality of the hybrid compensators. The simulation results authorize that the equivalent mixture of SC and STATCOM has a steady and fastest response. The results also reveal the supremacy of the firefly algorithm based optimal PI controller over the conventional PI controller. The harmonic present in the inverter side AC quantities is also calculated under steady state operation to assure the quality of power supply.
\end{abstract}

Keywords: MTDC, Very weak AC system, Hybrid RPC, PI controller, Firefly Algorithm.

\section{INTRODUCTION}

Due to the flexibility in the power flow control, reduction in number of converter units and easy connection of a new offshore load/generation terminal [1-3], the MTDC power transmission technology has attracted a number of researchers. During occurrence of the fault, in an MTDC system without appropriate control and protection, the fault at one terminal will affect the other terminals. Under such circumstances of the MTDC system, by presuming that the blocking of the converter is successful, special control and protection is offered. On the other hand, this presumption is not necessarily valid in terms of the practical operation of converters in the HVDC system [4-6]. Hence, it is worth identifying the possible hazard to the MTDC system by propagating the fault at one terminal without blocking the converters. During such situations, the fault recovery time and level of temporary over voltage (TOV) are the major criterion to be studied, which are often decided by the performance of reactive power compensator at AC side and PI controllers on the DC system. Therefore, investigating the performance of those devices is necessary to reveal the control and protection.

Further, the behavior of HVDC systems plays ever greater roles in the performance of entire AC/DC power systems. In order to improve stability of the power grid consists of HVDC system, it is necessary to know the mechanisms of the interactions between an HVDC system and an AC network. The importance of this interaction basically depends on the strength of the AC system at the converter bus [7], which is typically shown by short circuit ratio (SCR). The following SCR values[8] can be applied to classify AC systems: a) a strong $\mathrm{AC}$ system $\mathrm{SCR}>3$, b) a weak AC system $2 \leq \mathrm{SCR}<3$, c) a very weak AC system $\mathrm{SCR}<2$.

Numerous works have been practiced to identify the interaction between very weak AC networks and HVDC systems. The performance of the monopolar HVDC system is analyzed with dynamic voltage control devices[9] such as fixed capacitor (FC), SC, SVC and a mix of the SC and $\mathrm{SVC}$ at the inverters of very weak AC systems under AC and DC disturbances. The possibility to interconnect AC/DC systems, leading to very weak SCR [10], is exposed by allowing the STATCOM for reactive power compensation. A multilevel gate turn-off (GTO) thyristor inverter as an advanced static var compensator [11] is projected for a monopolar HVDC system and tinted its main benefits. The suppressors of temporary over voltage (TOV) and DC power recovery performance of the advanced static var compensator is investigated at an HVDC converter terminal with very low SCR AC system and the simulation results are compared under various $\mathrm{AC}$ and DC disturbances with the reactive power compensation options available. 


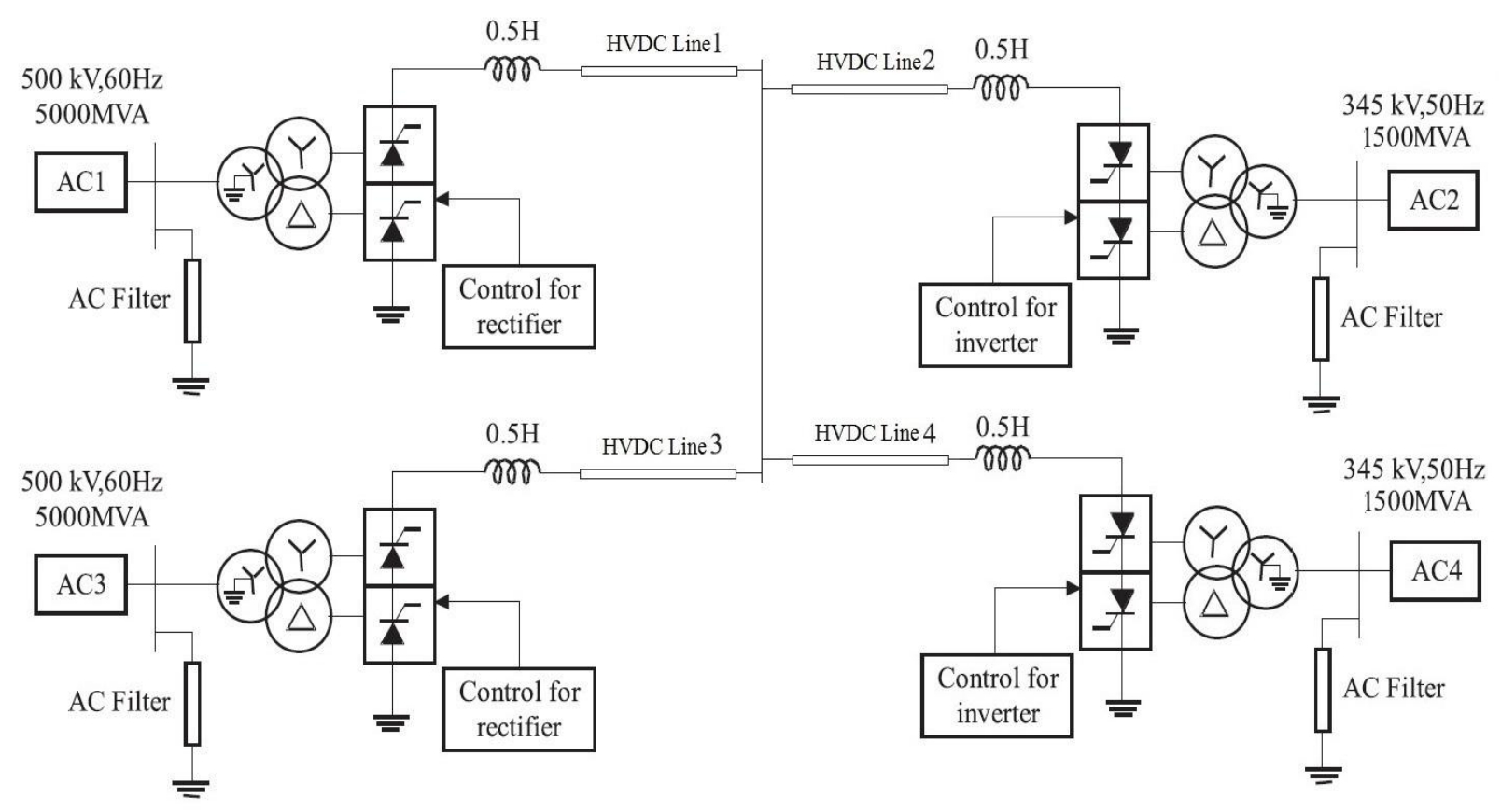

Fig-1: Four-terminal HVDC transmission system model feeding very weak AC networks

In order to make the analysis complete, it is highly necessary to consider the suppression of TOV and fault recovery performances for an HVDC system feeding a very weak AC network with the following hybrid RPC's as well, $\mathrm{SC}+\mathrm{SVC}, \quad \mathrm{SC}+\mathrm{STATCOM}$ and SVC+STATCOM. Therefore, in [12] transient performance has been carried out for an HVDC transmission system connected to very weak AC network with the following RPC's: SC, SVC, STATCOM, SC+SVC, SC+STATCOM and SVC+STATCOM. As an addition, in this paper, the detailed simulation study carried out in the monopolar HVDC system is extended to an MTDC system by analyzing the DC power recovery performance and suppression of TOV during various transient fault conditions. The harmonics investigation is also done under steady state to insure the quality of power supply on inverter AC side. Referable to the unfitness of the simple fixed gain PI controllers used for the rectifier and the inverter control of an HVDC system under various abnormal conditions, many intelligent techniques have been accompanied [13-16], for proper tuning of the controller parameters. Up till now, in all those tuning methods the principal signals used to fix the proportional and integral gains of the pole controller (both the rectifier and the inverter) are current error and its derivative. On the other hand, for the inverter gamma controller, the gamma error and its derivative are used. In this paper, minimization of the rectifier and the inverter DC power errors are viewed as an objective function which is accomplished by the firefly optimization algorithm, to assign the PI gains of the respective PI controller. To prove the strength of the firefly algorithm based optimal PI controller on transient performance of HVDC system, it has been compared with conventional PI controls.

\section{MODELLING OF MTDC TRANSMISSION}

\section{SYSTEM}

A line commutated converter based four-terminal HVDC system feeding two strong AC networks [17], in which inverter side $\mathrm{AC}$ networks are replaced by very weak $\mathrm{AC}$ networks as shown in the Fig. 1. The rectifier side AC system of $500 \mathrm{kV}, 5000 \mathrm{MVA}, 60 \mathrm{~Hz}$ is connected to the inverter side $\mathrm{AC}$ system of $345 \mathrm{kV}, 1500 \mathrm{MVA}, 50 \mathrm{~Hz}$ through an HVDC network. Generally, the AC system is represented by damped LLR equivalents. The Passive filters of 450MVAr are connected on the source side to eliminate the $11^{\text {th }}$ and $13^{\text {th }}$ (the double tuned type) order and above $24^{\text {th }}$ (second order high pass filter) order current harmonics and the synchronous and/or the static compensator is used (150MVAr) for reactive power compensation. The rectifier and the inverter are 12-pulse converters. The DC network model consists of a smoothing reactor for the rectifier and the inverter bridges, a passive filter of double tuned type to mitigate the $12^{\text {th }}$ and $24^{\text {th }}$ order DC voltage harmonics and the DC line. The DC link of $1500 \mathrm{~km}$ is modelled as a distributed parameter line model with lumped losses. The rectifier is equipped with a current controller to keep the DC system current constant. The inverter is provided with a current controller to keep the DC system current constant and a constant extinction angle or gamma controller. The reference current for the current controllers is obtained from the master controller output through the voltage dependent current order limiter (VDCOL). In order to protect the rectifier and the inverter DC protection functions are implemented in each converter. In the inverter side AC network, the following six reactive power compensator options are studied. 


\section{$2.1 \mathrm{SC}$}

The SC model of 150MVAr shown in Fig. 2 (a) is represented with the simplified synchronous machine block which models, both the electrical and mechanical characteristics of a simple synchronous machine. The SC uses the solid static excitation system.

\subsection{SVC}

A 150MVAr SVC is shown in Fig. 2 (b) regulates voltage on a $345 \mathrm{kV}$ system. The SVC consists of a $345 \mathrm{kV} / 16 \mathrm{kV}$, 168MVA coupling transformer, one 60MVAr TCR bank and one 180MVAr TSC connected to the secondary side of the transformer. Switching the TSC in and out allows a continuous variation of the secondary reactive power from zero to 180MVAr capacitive, whereas phase control of the TCR allows a continuous variation from zero to $60 \mathrm{MVAr}$ inductive.

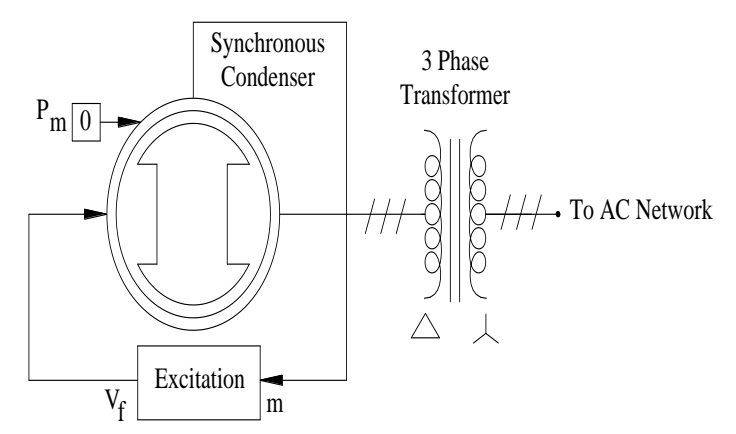

(a) SC

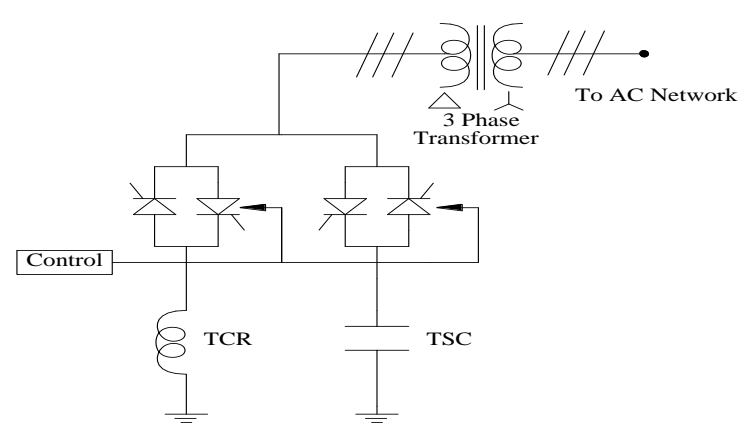

(b) SVC

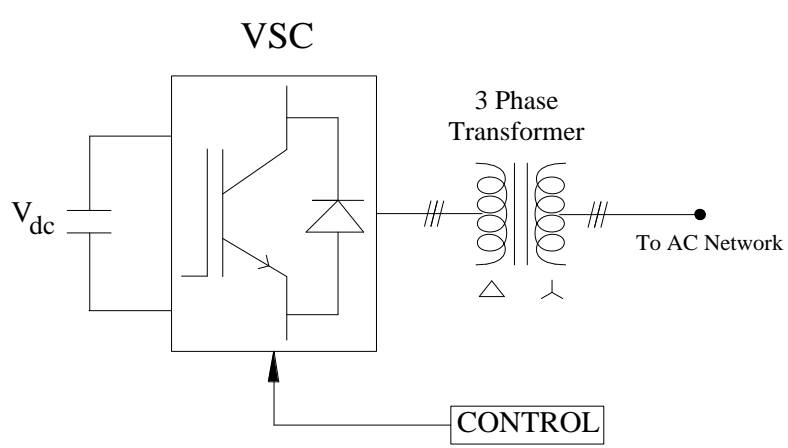

(c) STATCOM

\subsection{STATCOM}

The STATCOM) shown in Fig. 2 (c) is located at the inverter side of the HVDC link and has a rating of \pm 150 MVAr. This STATCOM is a typical simple PWM voltage source converter (VSC). It consists of a 6 pulse VSC inverter and a series connected Capacitors which act as a variable DC voltage source. Based on a VSC, the STATCOM regulates system voltage by absorbing or generating reactive power.

\subsection{An Equal Mix of SC and SVC}

The SC and SVC (-90MVAr, +30MVAr) are connected to the inverter bus in this scheme with the rating of the SC halved to 75Mvar. In steady state the SC and SVC each supply 75MVAr.

\subsection{An Equal Mix of SC and STATCOM}

The SC and STATCOM ( $\pm 75 \mathrm{MVAr})$ are connected to the inverter bus in this scheme with the rating of the SC halved to 75Mvar. In steady state the SC and STATCOM each supply 75MVAr.

\subsection{An Equal Mix of SVC and STATCOM}

The SVC (-90MVAr, +30MVAr) and STATCOM $( \pm 75 \mathrm{MVAr})$ are connected to the inverter bus in this scheme. In steady state the SVC and STATCOM each supply 75MVAr.

\section{APPLICATION OF FIREFLY ALGORITHM FOR OBTAINING OPTIMAL GAIN VALUES FOR PI CONTROLLERS}

In this paper, optimization of the rectifier and the inverter side DC power error is picked as a prime objective function which has to be minimized. To realize the same DC power (PDCMEA) and its reference (PDCREF) is compared to get the error signal. The integral square error of the rectifier DC power error and inverter DC power error are processed by the firefly algorithm [18-20] to fix the gain of the rectifier current PI controller and to fix the gain of the both inverter current PI controller and the gamma PI controller respectively. This approach ensures the reduced computational procedure, faster recovery and reduced TOV. The schematic diagram of the firefly algorithm based tuning technique is shown in Fig. 3. The general flow chart for minimization of the rectifier/ the inverter DC power error function using firefly algorithm is shown in Fig. 4.

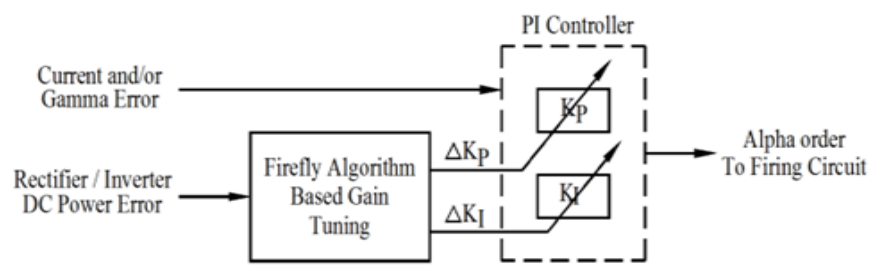

Fig-3: Schematic diagram of the firefly algorithm based tuning technique. 


\section{SIMULATION RESULTS AND DISCUSSION}

In order to know the interaction between $\mathrm{AC}$ network and HVDC systems, MATLAB simulation model is implemented based on the data [21]. On the inverter AC side the following RPC's are considered for analysis: SC, SVC, STATCOM, SC+SVC, SC+STATCOM and SVC+STATCOM. In all the cases simulated steady state

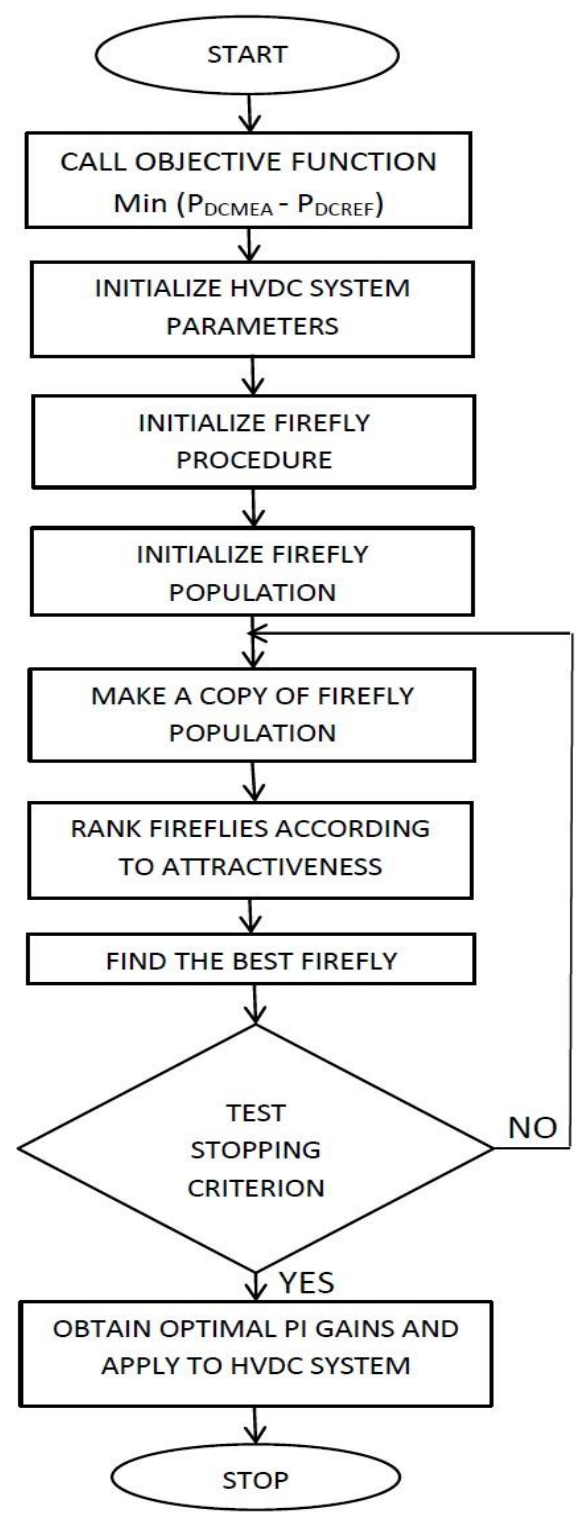

Fig-4: Flowchart for minimization of the rectifier / the inverter DC power error function using firefly algorithm

AC voltage and current waveforms at the inverter AC side and their harmonic spectrums are observed to assure the quality of the AC supply. The transient performance of the HVDC system is analyzed in the presence of various RPC'S for a duration of two seconds under different fault conditions to study the suppression of TOV and fault recovery. For the purposes of comparison, identical fault duration of 0.05 seconds was used for all types of faults. During the transient performance analysis, faults are considered only in rectifier station 1 and inverter station 1 and their impact on inverter station 1 and 2 is presented (Since the rectifier 1 and 2 and inverter 1 and 2 are identical in the system under study). The inverter side RMS AC voltage waveforms are observed during various $\mathrm{AC}$ faults and DC fault on the rectifier side to study the TOV suppression capability of the proposed firefly algorithm based PI controller. For analyzing the fault recovery capability with the proposed firefly algorithm based PI controller, the inverter DC power is observed, under various $\mathrm{AC}$ faults and DC faults at rectifier and inverter side. In all the cases, the TOV suppression and fault clearance capability of the firefly algorithm based PI controller are compared with conventional PI controller of an HVDC transmission system.

\subsection{Inverter Side AC Harmonics}

The inverter side AC voltage and current waveforms and their harmonic spectrums during steady state operation are shown in Fig. 5, 6 and the results are listed in Table 1. From the inverter side $\mathrm{AC}$ waveforms and their harmonic spectrum, it is found that in all the cases the voltage and current are equal to $1 \mathrm{p} . \mathrm{u}$ and the harmonics are within tolerable limit. The $11^{\text {th }}$ and $13^{\text {th }}$ current harmonics are the foremost harmonics on the inverter AC side.

\subsection{Temporary Overvoltage}

When disturbances occur on the DC line or at the rectifier side, commonly temporary over voltage happens. It is usual practice a large number RLC based filters are provided in the inverter side of the HVDC system, in order to supply the part of necessary reactive power. During rectifier side AC or DC faults (the inverter side has no faults), the DC is blocked, and hence the reactive power of those filters will flow into the AC system, which often causes TOV. In order to suppress the TOV, the reactive power compensator and DC system PI controllers should respond quickly otherwise the TOV could be very high and could damage the insulation of the equipment. The ability of TOV suppression of various RPC's is demonstrated with the proposed firefly algorithm based PI controller and also compared to a conventional PI controller. From the inverter side RMS AC voltage waveforms shown in Fig. 7, 8 and the results listed in Table 2, the occurrence of TOV with the presence of a conventional PI controller for various RPC's can be understood. The hybrid RPC's (SC+SVC, SC+STATCOM and SVC+STATCOM) has improved TOV controlling capability, than their individual performance (SC, SVC, and STATCOM). In particular, SC+STATCOM have very less TOV among the various RPC's. The TOV values further reduced due to the application firefly algorithm based PI controller compared to conventional PI controller.

\subsection{Fault Recovery}

The time taken by the HVDC system to recover the $80 \%$ of the pre-fault power after the fault clearance is known as DC power recovery time. The DC power recovery time is often desired the recovery ability of a DC system PI controller and the capability of the RPC's during system disturbances 

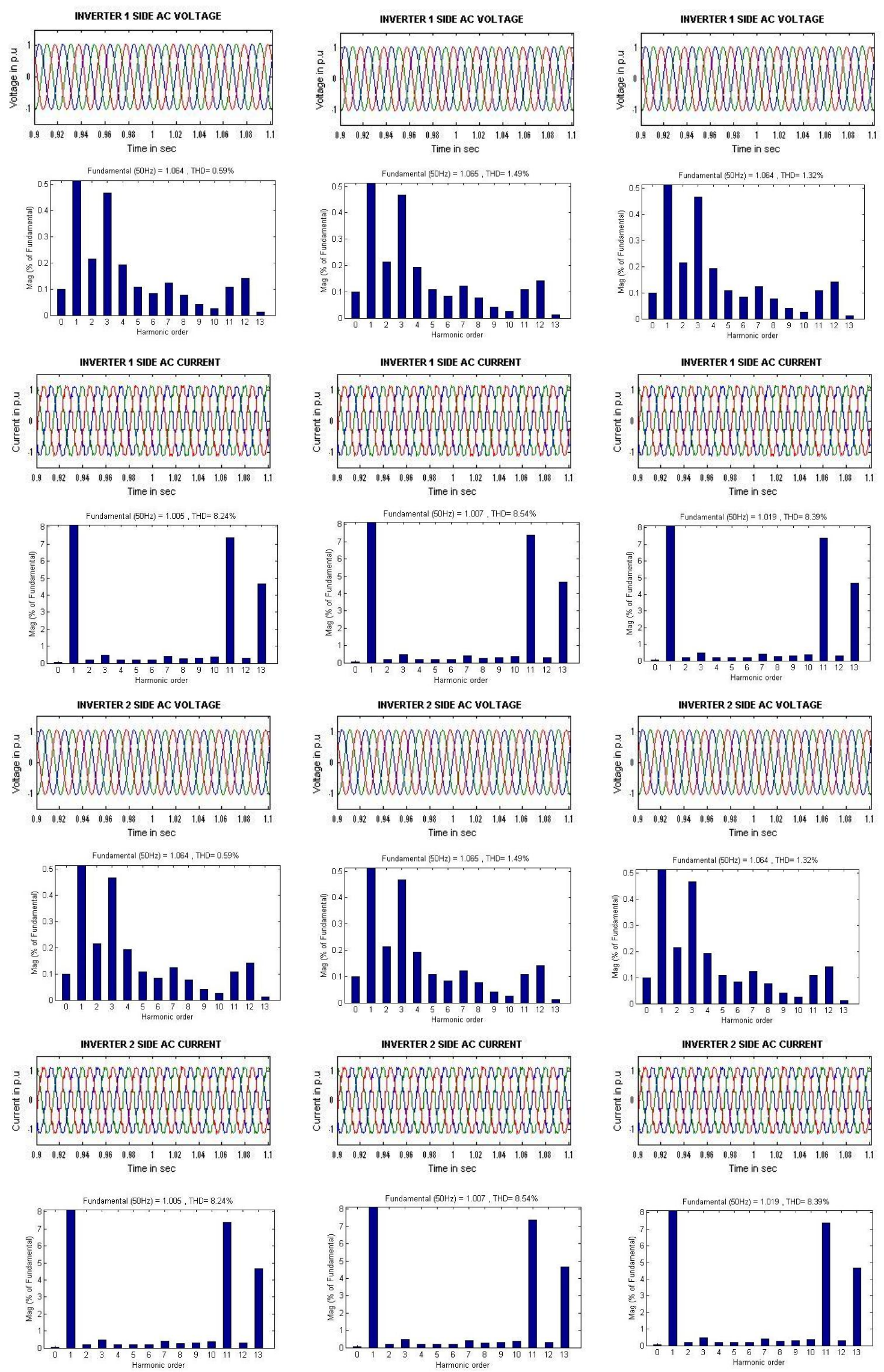

Fig-5: Inverter 1 and 2 sides AC waveforms and their harmonic spectrums during steady state operation -with SC (left), -with SVC (middle), -with STATCOM (right). 

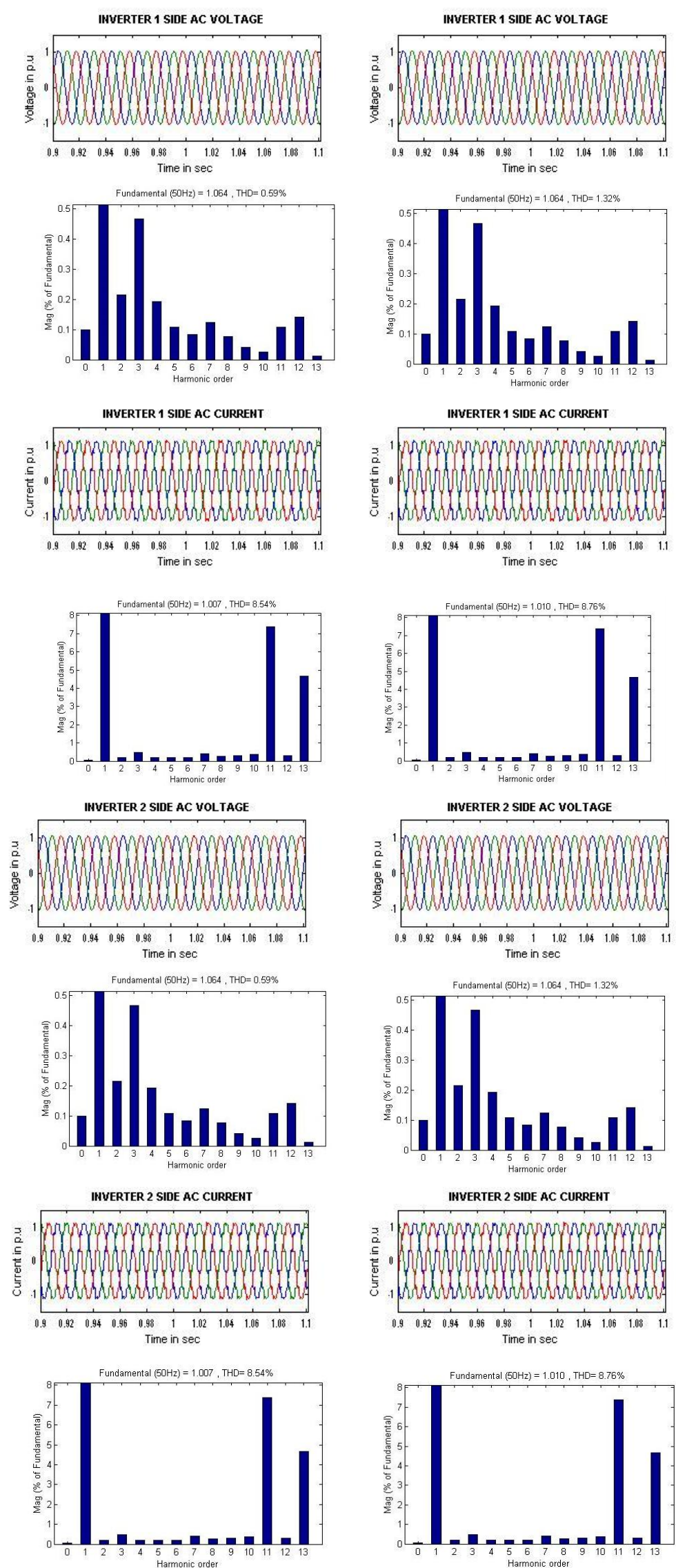

Fig-6: Inverter 1 and 2 sides AC waveforms and their harmonic spectrums during steady state operation -with SC+SVC (Left), with SC+STATCOM (Middle), -with SVC+STATCOM (Right).
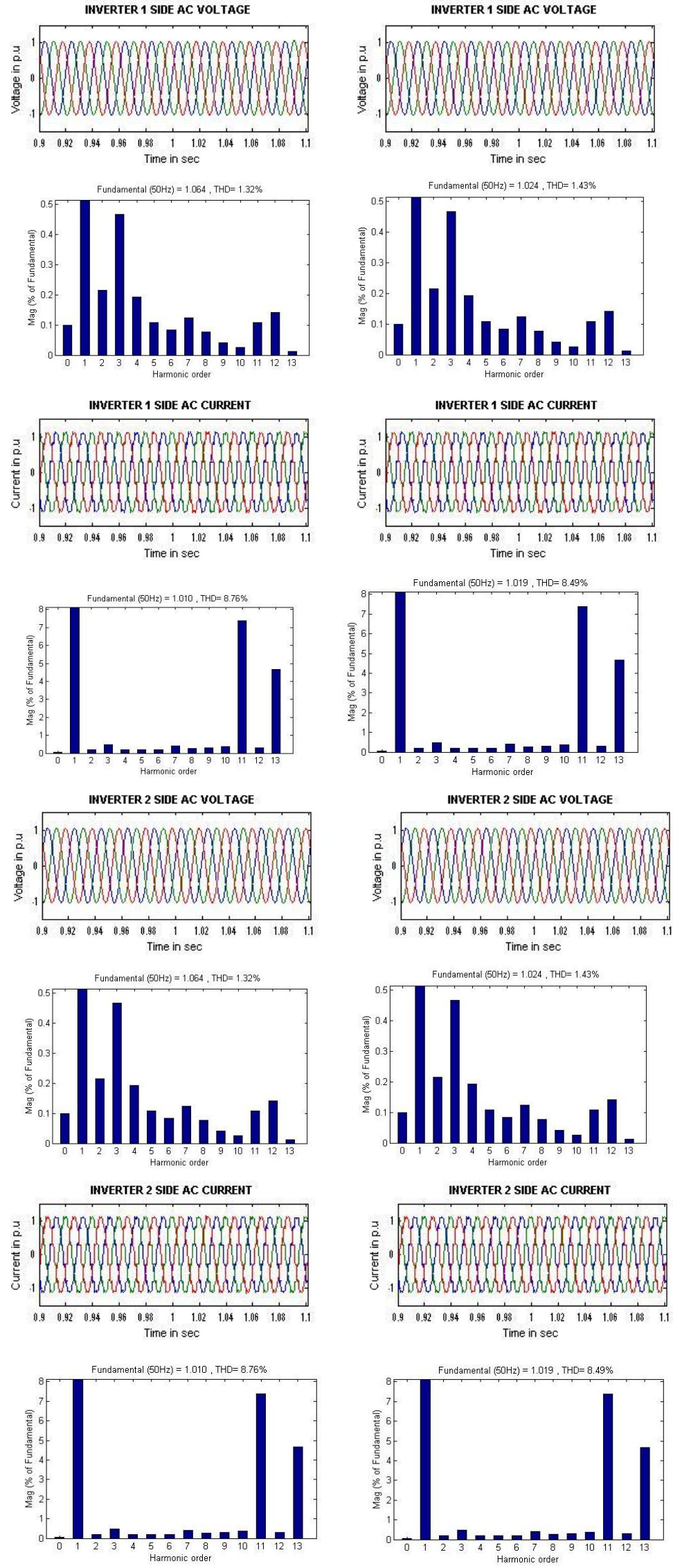

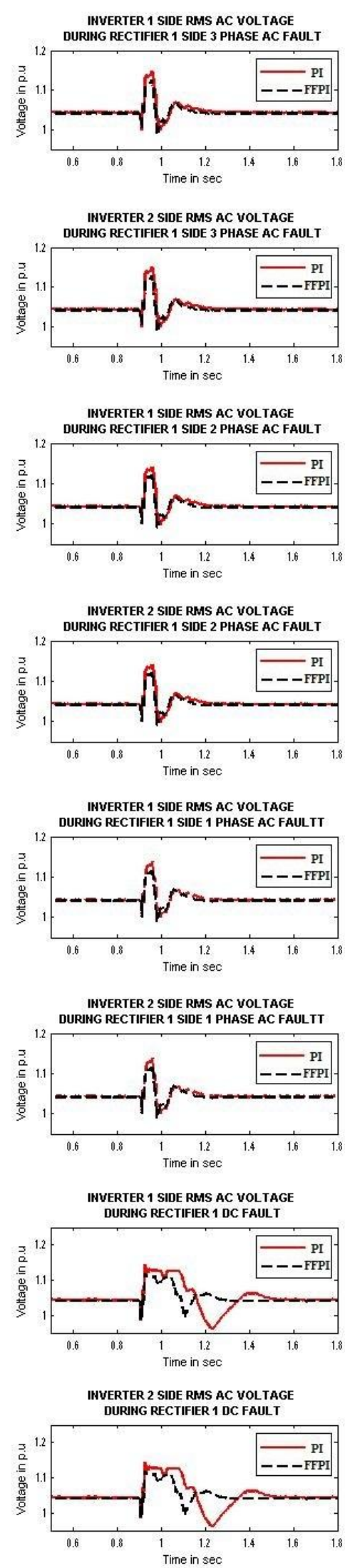
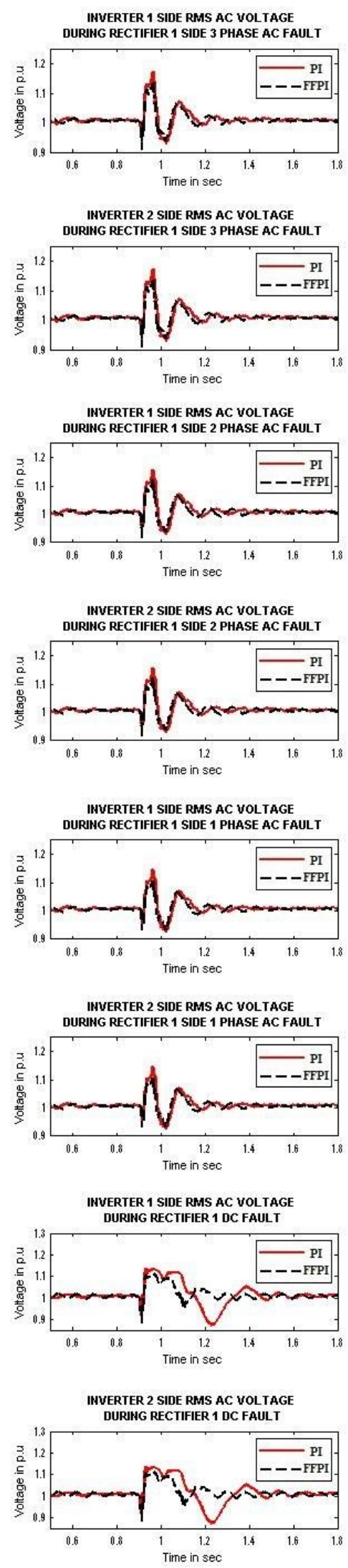
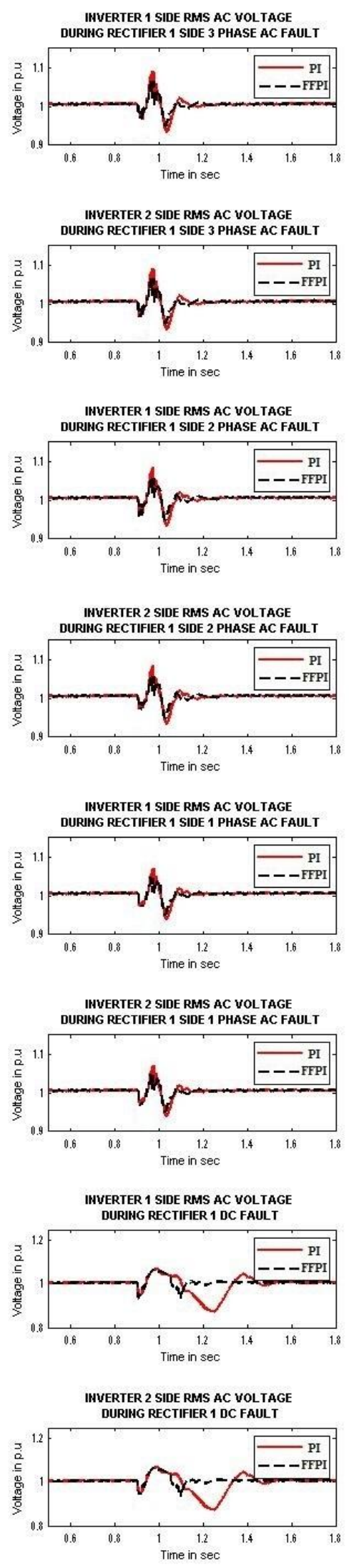

Fig-7: Inverter 1 and 2 AC bus RMS voltage when disturbances occur on the DC line or at the rectifier AC side -with SC (left), with SVC (middle), -with STATCOM (right). 

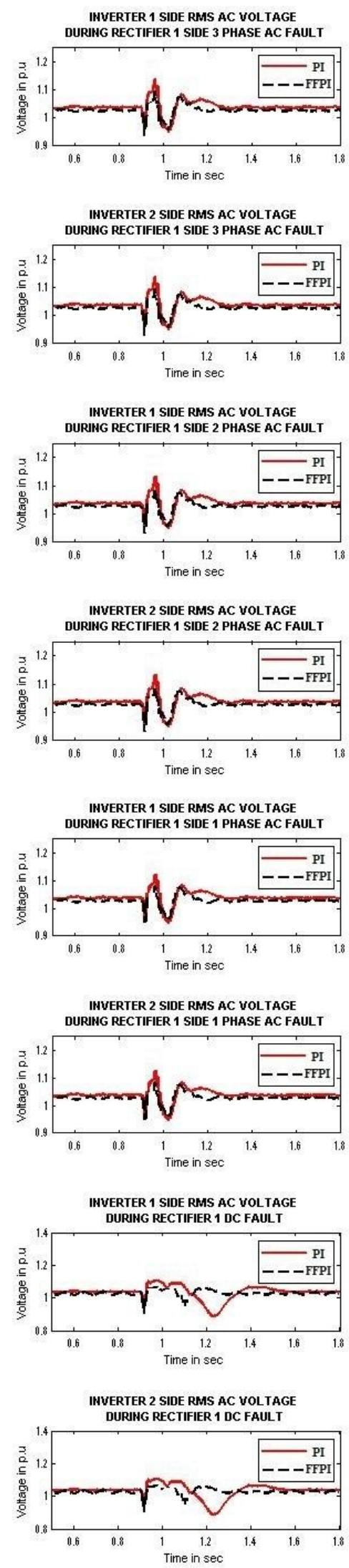
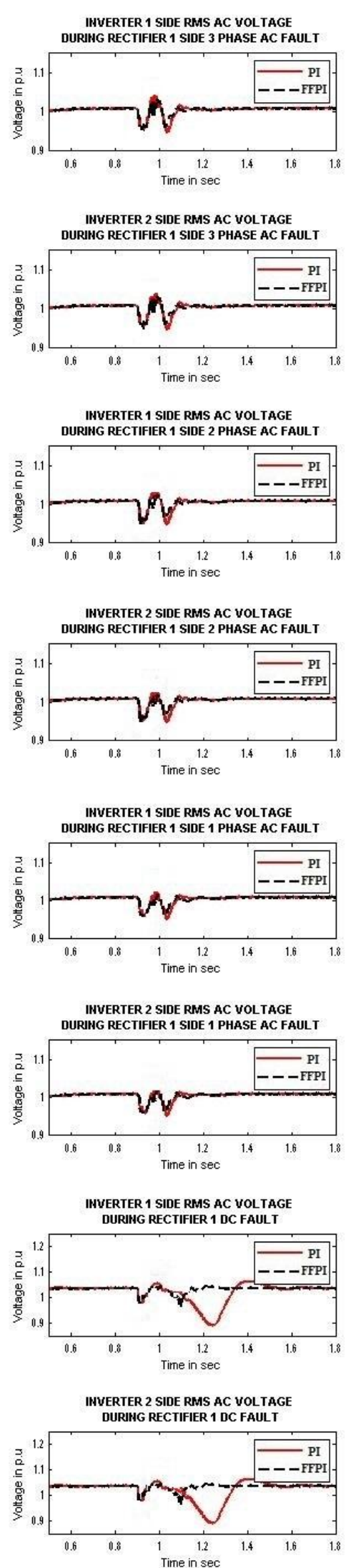
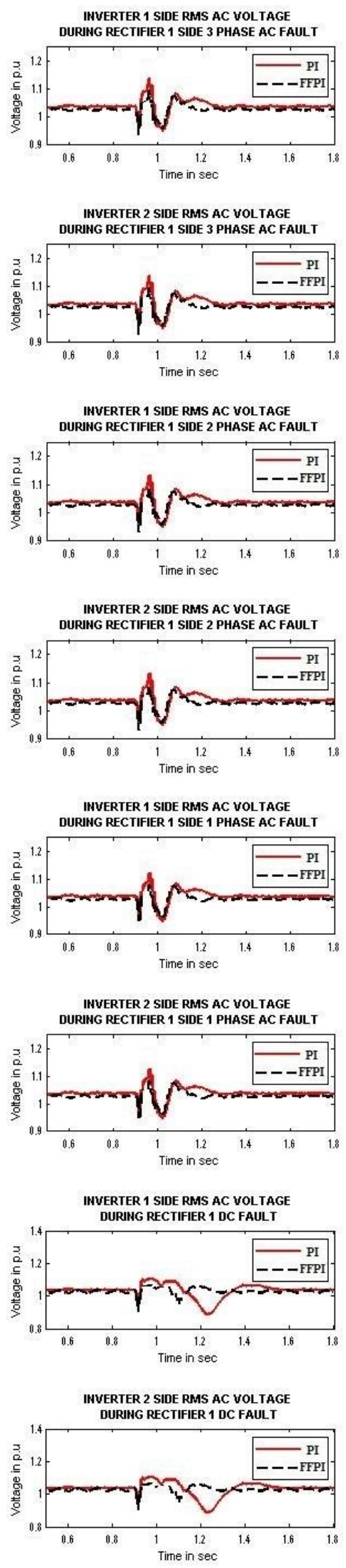

Fig-8: Inverter 1 and $2 \mathrm{AC}$ bus RMS voltage when disturbances occur on the DC line or at the rectifier AC side -with SC+SVC (Left), - with SC+STATCOM (Middle), -with SVC+STATCOM (Right). 

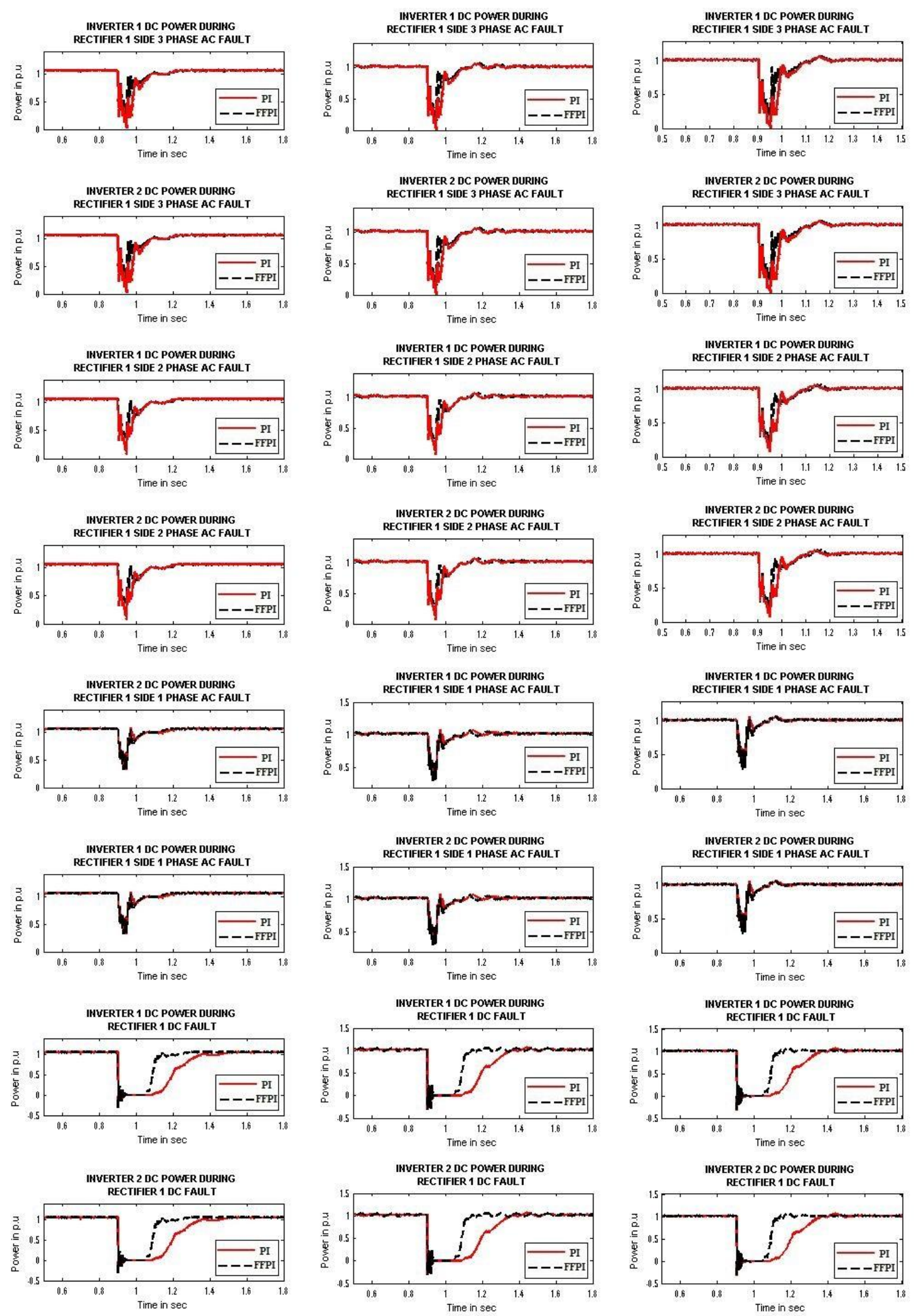

.Fig-9: Inverter 1 and 2 DC power when AC and DC disturbances occur on the rectifier 1 side -with SC (left), -with SVC (middle), -with STATCOM (right). 

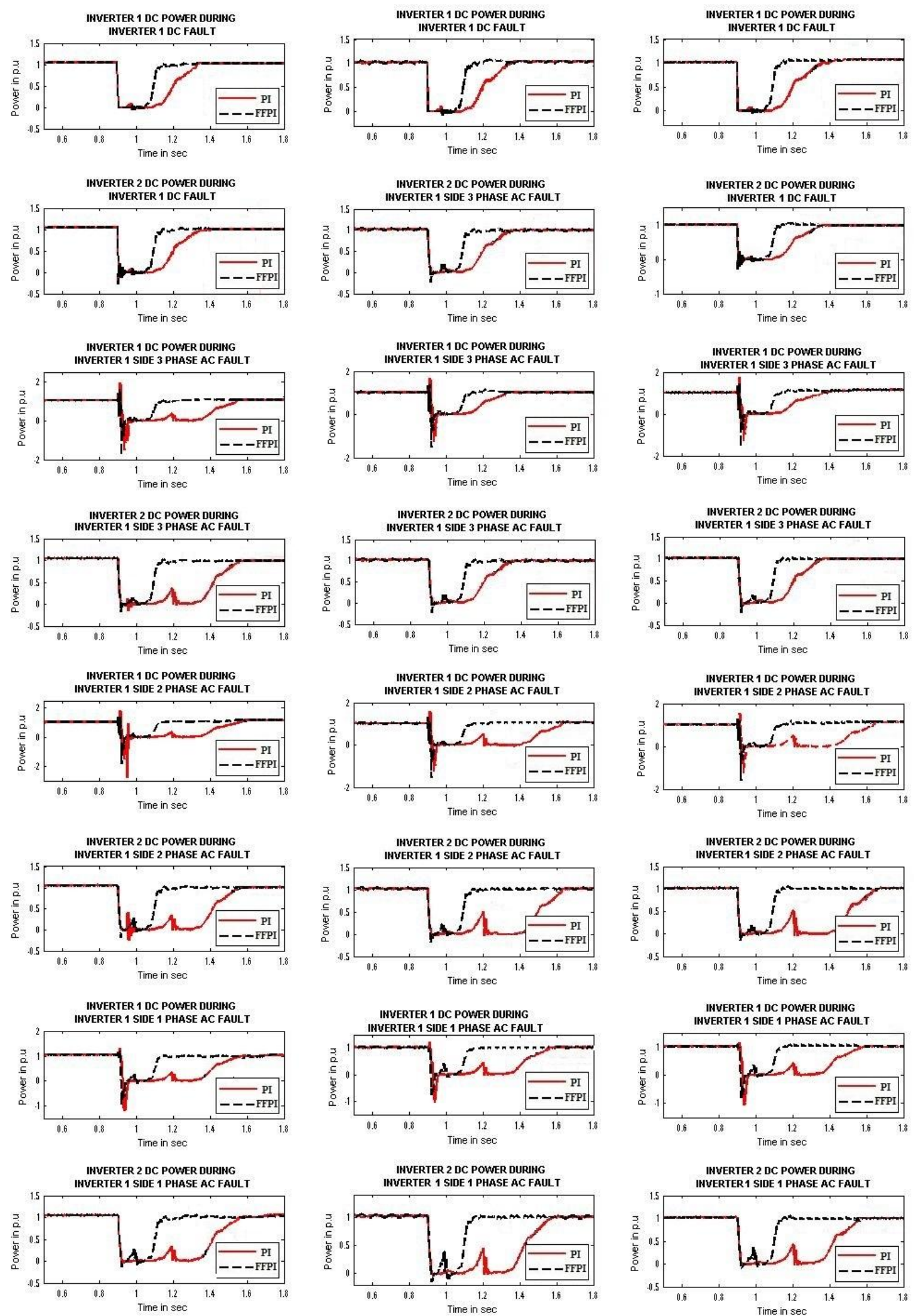

Fig-10: Inverter 1 and 2 DC power when AC and DC disturbances occur on the inverter 1 side -with SC (left), -with SVC (middle), -with STATCOM (right). 

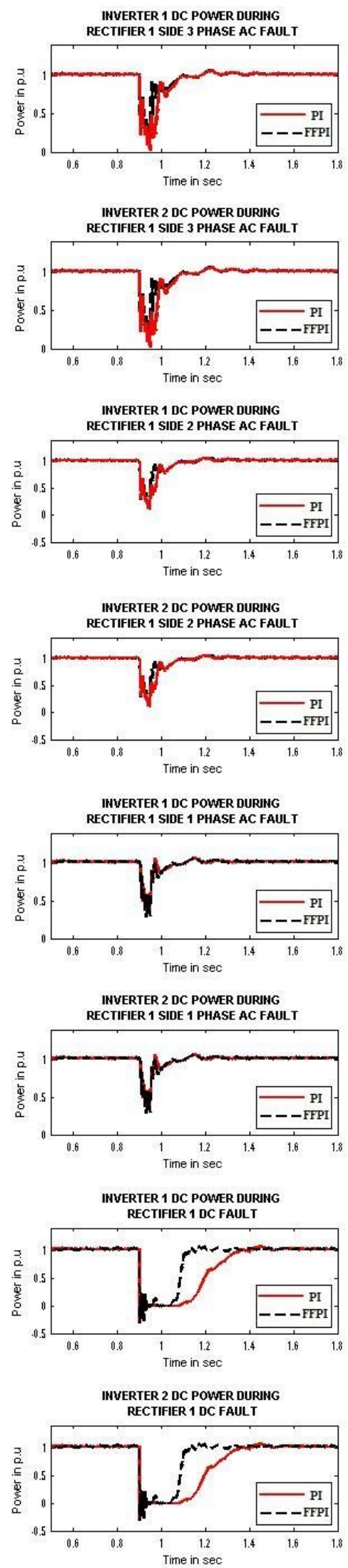
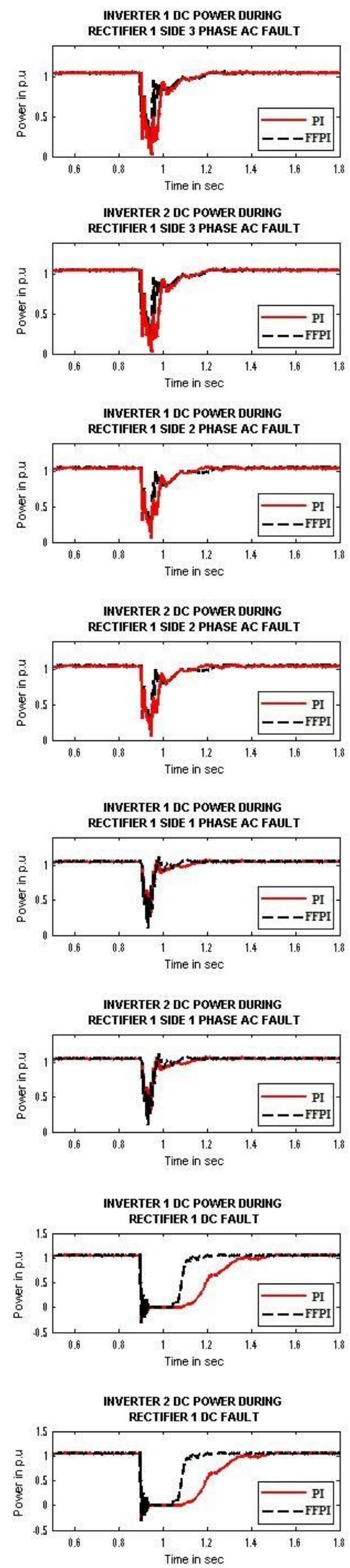
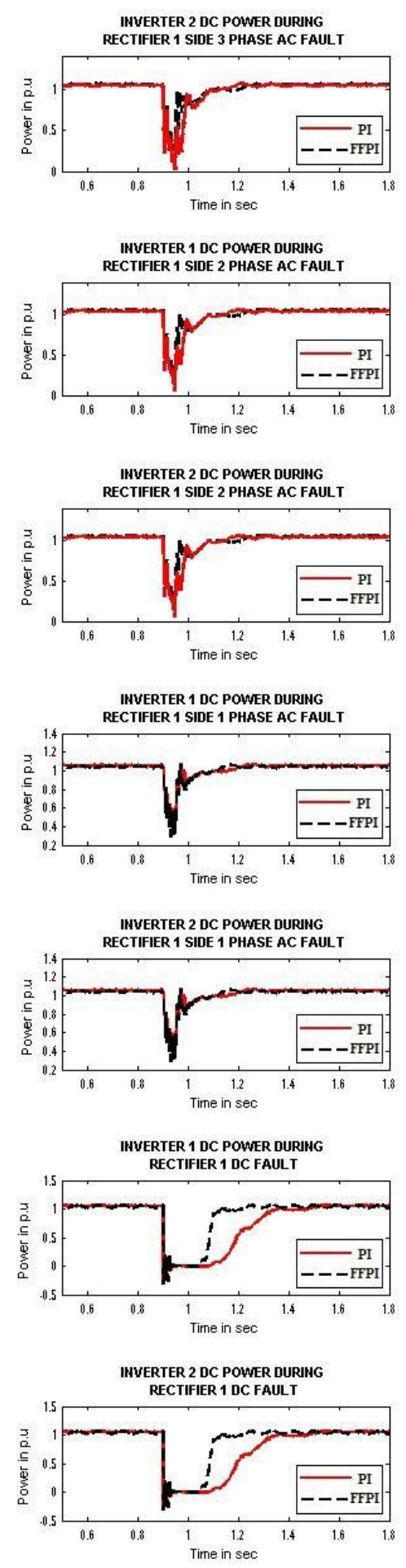

Fig-11: Inverter 1 and $2 \mathrm{DC}$ power when AC and DC disturbances occur on the rectifier 1 side -with SC+SVC (Left), -with SC+STATCOM (Middle), -with SVC+STATCOM (Right). 

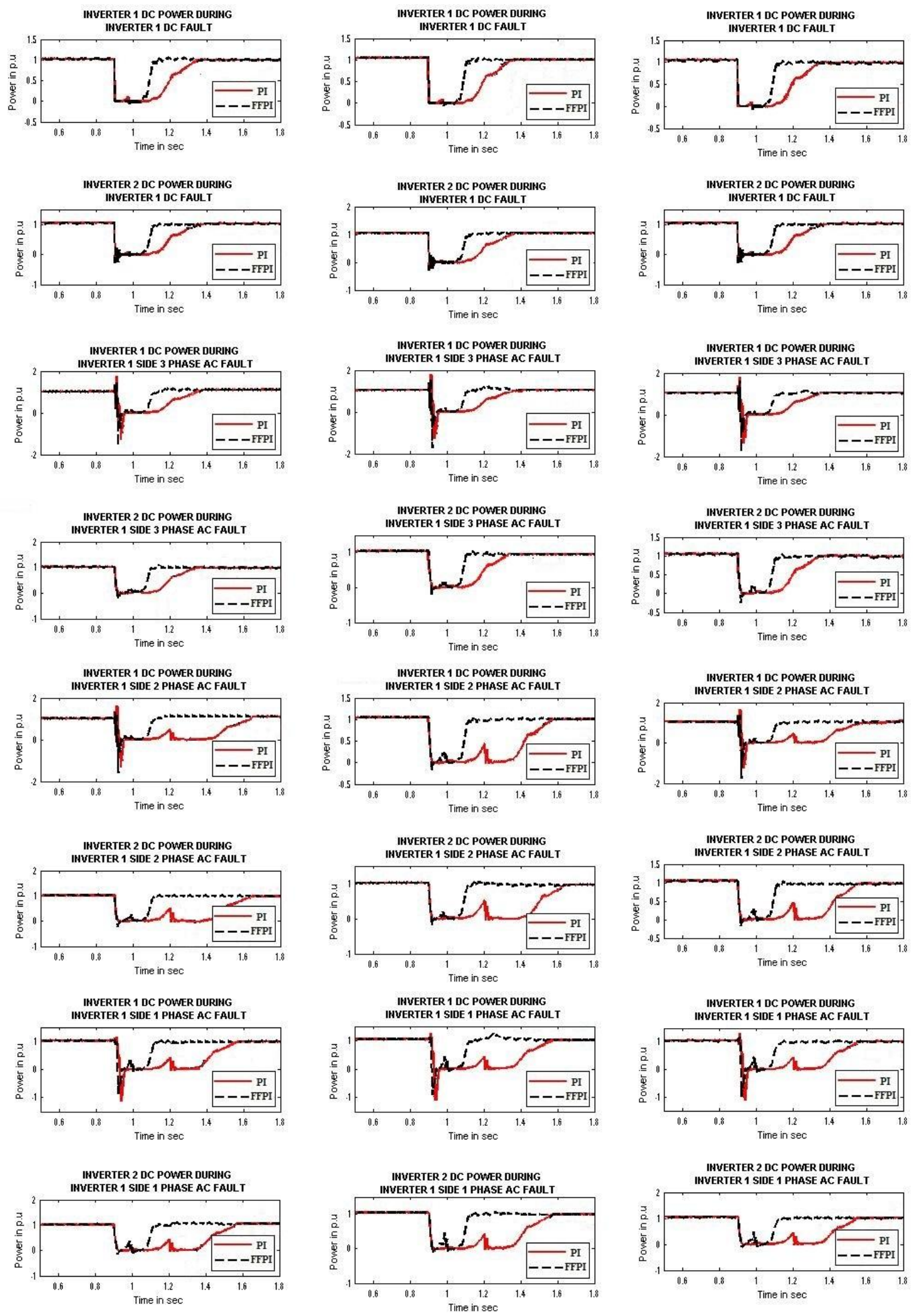

Fig-12: Inverter 1 and 2 DC power when AC and DC disturbances occur on the inverter 1 side -with SC+SVC (Left), -with SC+ STATCOM (Middle), -with SVC+STATCOM (Right). 
Table-1: Harmonics present in the inverter side AC quantities.

\begin{tabular}{|l|l|l|l|l|l|l|l|}
\hline \multicolumn{2}{|}{$\begin{array}{l}\text { \% AC Harmonics } \\
\text { for various RPC's }\end{array}$} & SC & SVC & STATCOM & SC+SVC & $\begin{array}{l}\text { SC+ } \\
\text { STATCOM }\end{array}$ & $\begin{array}{l}\text { SVC+ } \\
\text { STATCOM }\end{array}$ \\
\hline \multirow{2}{*}{ Voltage } & Inverter 1 & 0.59 & 1.49 & 1.32 & 0.59 & 1.32 & 1.43 \\
\cline { 2 - 8 } & Inverter 2 & 0.59 & 1.49 & 1.32 & 0.59 & 1.32 & 1.43 \\
\hline \multirow{2}{*}{ Current } & Inverter 1 & 8.24 & 8.54 & 839 & 8.54 & 8.76 & 8.49 \\
\cline { 2 - 8 } & Inverter 2 & 8.24 & 8.54 & 839 & 8.54 & 8.76 & 8.49 \\
\hline
\end{tabular}

Table-2: Level of Over voltage when disturbances occur on the DC line or at the rectifier 1 side during DC block.

\begin{tabular}{|c|c|c|c|c|c|c|c|c|c|}
\hline \multirow{2}{*}{\multicolumn{2}{|c|}{$\begin{array}{l}\text { TOV for Various } \\
\text { RPC's in p.u }\end{array}$}} & \multicolumn{2}{|c|}{$\begin{array}{l}\text { Rectifier } 1 \text { side } 3 \Phi \\
\text { AC fault }\end{array}$} & \multicolumn{2}{|c|}{$\begin{array}{l}\text { Rectifier } 1 \text { side } 2 \Phi \\
\text { AC fault }\end{array}$} & \multicolumn{2}{|c|}{$\begin{array}{l}\text { Rectifier } 1 \text { side } 1 \Phi \\
\text { AC fault }\end{array}$} & \multirow{2}{*}{\multicolumn{2}{|c|}{\begin{tabular}{l|l}
$\begin{array}{l}\text { Rectifier } \quad 1 \quad \text { DC } \\
\text { fault }\end{array}$ \\
$\begin{array}{l}\text { Inverter } \\
1\end{array}$ & $\begin{array}{l}\text { Inverter } \\
2\end{array}$ \\
\end{tabular}}} \\
\hline & & $\begin{array}{l}\text { Inverter } \\
1\end{array}$ & $\begin{array}{l}\text { Inverter } \\
2\end{array}$ & $\begin{array}{l}\text { Inverter } \\
1\end{array}$ & $\begin{array}{l}\text { Inverter } \\
2\end{array}$ & $\begin{array}{l}\text { Inverter } \\
1\end{array}$ & $\begin{array}{l}\text { Inverter } \\
2\end{array}$ & & \\
\hline \multirow{2}{*}{ SC } & PI & 1.1844 & 1.1844 & 1.1675 & 1.1675 & 1.1462 & 1.1462 & 1.1421 & 1.1421 \\
\hline & FFPI & 1.1565 & 1.1565 & 1.1382 & 1.1382 & 1.1164 & 1.1164 & 1.1208 & 1.1208 \\
\hline \multirow{2}{*}{ SVC } & PI & 1.1956 & 1.1956 & 1.1795 & 1.1795 & 1.1501 & 1.1501 & 1.1558 & 1.1558 \\
\hline & FFPI & 1.1724 & 1.1724 & 1.1511 & 1.1511 & 1.1225 & 1.1225 & 1.1311 & 1.1311 \\
\hline \multirow{2}{*}{ STATCOM } & PI & 1.0932 & 1.0932 & 1.0885 & 1.0885 & 1.0665 & 1.0665 & 1.0937 & 1.0937 \\
\hline & FFPI & 1.0624 & 1.0624 & 1.0634 & 1.0634 & 1.0398 & 1.0398 & 1.0683 & 1.0683 \\
\hline \multirow{2}{*}{$\begin{array}{l}\text { SC+ } \\
\text { SVC }\end{array}$} & PI & 1.1457 & 1.1457 & 1.1298 & 1.1298 & 1.1037 & 1.1037 & 1.1064 & 1.1064 \\
\hline & FFPI & 1.1168 & 1.1168 & 1.1037 & 1.1037 & 1.0724 & 1.0724 & 1.0885 & 1.0885 \\
\hline \multirow{2}{*}{$\begin{array}{l}\text { SC+ } \\
\text { STATCOM }\end{array}$} & PI & 1.0475 & 1.0475 & 1.0337 & 1.0337 & 1.0268 & 1.0268 & 1.0465 & 1.0465 \\
\hline & FFPI & 1.0295 & 1.0295 & 1.0256 & 1.0256 & 1.0175 & 1.0175 & 1.0256 & 1.0256 \\
\hline \multirow{2}{*}{$\begin{array}{l}\text { SVC+ } \\
\text { STATCOM }\end{array}$} & PI & 1.1372 & 1.1372 & 1.1141 & 1.1141 & 1.0833 & 1.0833 & 1.0956 & 1.0956 \\
\hline & FFPI & 1.1121 & 1.1121 & 1.0962 & 1.0962 & 1.0646 & 1.0646 & 1.0788 & 1.0788 \\
\hline
\end{tabular}

Table-3: Inverter 1 and 2 DC power recovery time when AC and DC disturbances occur on the rectifier 1 side.

\begin{tabular}{|c|c|c|c|c|c|c|c|c|c|}
\hline \multirow{2}{*}{\multicolumn{2}{|c|}{$\begin{array}{l}\text { DC power } \\
\text { recovery time for } \\
\text { Various RPC's in } \\
\text { seconds }\end{array}$}} & \multicolumn{2}{|c|}{$\begin{array}{l}\text { Rectifier } 1 \text { Side } 3 \Phi \\
\text { AC fault }\end{array}$} & \multicolumn{2}{|c|}{$\begin{array}{l}\text { Rectifier } 1 \text { side } 2 \Phi \\
\text { AC fault }\end{array}$} & \multicolumn{2}{|c|}{$\begin{array}{l}\text { Rectifier } 1 \text { side } 1 \Phi \\
\text { AC fault }\end{array}$} & \multicolumn{2}{|l|}{$\begin{array}{l}\text { Rectifier } \\
\text { DC fault }\end{array}$} \\
\hline & & $\begin{array}{l}\text { Inverter } \\
1\end{array}$ & $\begin{array}{l}\text { Inverter } \\
2\end{array}$ & $\begin{array}{l}\text { Inverter } \\
1\end{array}$ & $\begin{array}{l}\text { Inverter } \\
2\end{array}$ & $\begin{array}{l}\text { Inverter } \\
1\end{array}$ & $\begin{array}{l}\text { Inverter } \\
2\end{array}$ & $\begin{array}{l}\text { Inverter } \\
1\end{array}$ & $\begin{array}{l}\text { Inverter } \\
2\end{array}$ \\
\hline \multirow{2}{*}{ SC } & PI & 0.090 & 0.090 & 0.079 & 0.079 & 0.053 & 0.053 & 0.399 & 0.399 \\
\hline & FFPI & 0.044 & 0.044 & 0.037 & 0.037 & 0.022 & 0.022 & 0.189 & 0.189 \\
\hline \multirow{2}{*}{ SVC } & PI & 0.099 & 0.099 & 0.085 & 0.085 & 0.060 & 0.060 & 0.412 & 0.412 \\
\hline & FFPI & 0.049 & 0.049 & 0.042 & 0.042 & 0.027 & 0.027 & 0.195 & 0.195 \\
\hline \multirow{2}{*}{ STATCOM } & PI & 0.084 & 0.084 & 0.075 & 0.075 & 0.048 & 0.048 & 0.384 & 0.384 \\
\hline & FFPI & 0.039 & 0.039 & 0.032 & 0.032 & 0.019 & 0.019 & 0.178 & 0.178 \\
\hline \multirow{2}{*}{$\begin{array}{l}\text { SC+ } \\
\text { SVC }\end{array}$} & PI & 0.084 & 0.084 & 0.073 & 0.073 & 0.043 & 0.043 & 0.381 & 0.381 \\
\hline & FFPI & 0.038 & 0.038 & 0.033 & 0.033 & 0.015 & 0.015 & 0.158 & 0.158 \\
\hline \multirow{2}{*}{$\begin{array}{l}\text { SC+ } \\
\text { STATCOM }\end{array}$} & PI & 0.074 & 0.074 & 0.063 & 0.063 & 0.034 & 0.034 & 0.364 & 0.364 \\
\hline & FFPI & 0.025 & 0.025 & 0.021 & 0.021 & 0.007 & 0.007 & 0.148 & 0.148 \\
\hline \multirow{2}{*}{$\begin{array}{l}\text { SVC+ } \\
\text { STATCOM }\end{array}$} & PI & 0.083 & 0.083 & 0.072 & 0.072 & 0.041 & 0.041 & 0.374 & 0.374 \\
\hline & FFPI & 0.037 & 0.037 & 0.032 & 0.032 & 0.014 & 0.014 & 0.154 & 0.154 \\
\hline
\end{tabular}


Table-4: Inverter 1 and 2 DC power recovery time when AC and DC disturbances occur on the inverter 1 side.

\begin{tabular}{|c|c|c|c|c|c|c|c|c|c|}
\hline \multirow{2}{*}{\multicolumn{2}{|c|}{$\begin{array}{l}\text { DC } \\
\text { recovery time for } \\
\text { Various RPC's in } \\
\text { seconds }\end{array}$}} & \multicolumn{2}{|c|}{ Inverter 1DC fault } & \multicolumn{2}{|c|}{$\begin{array}{l}\text { Inverter } 1 \text { side } 3 \Phi \\
\text { AC fault }\end{array}$} & \multicolumn{2}{|c|}{$\begin{array}{l}\text { Inverter } 1 \text { side } 2 \Phi \\
\text { AC fault }\end{array}$} & \multicolumn{2}{|c|}{$\begin{array}{l}\text { Inverter } 1 \text { side } 1 \Phi \\
\text { AC fault }\end{array}$} \\
\hline & & $\begin{array}{l}\text { Inverter } \\
1\end{array}$ & $\begin{array}{l}\text { Inverter } \\
2\end{array}$ & $\begin{array}{l}\text { Inverter } \\
1\end{array}$ & $\begin{array}{l}\text { Inverter } \\
2\end{array}$ & $\begin{array}{l}\text { Inverter } \\
1\end{array}$ & $\begin{array}{l}\text { Inverter } \\
2\end{array}$ & $\begin{array}{l}\text { Inverter } \\
1\end{array}$ & $\begin{array}{l}\text { Inverter } \\
2\end{array}$ \\
\hline \multirow{2}{*}{ SC } & PI & 0.408 & 0.408 & 0.601 & 0.601 & 0.592 & 0.592 & 0.581 & 0.581 \\
\hline & FFPI & 0.192 & 0.192 & 0.194 & 0.194 & 0.190 & 0.190 & 0.185 & 0.185 \\
\hline \multirow{2}{*}{ SVC } & PI & 0.421 & 0.421 & 0.614 & 0.614 & 0.605 & 0.605 & 0.594 & 0.594 \\
\hline & FFPI & 0.195 & 0.195 & 0.201 & 0.201 & 0.196 & 0.196 & 0.190 & 0.190 \\
\hline \multirow{2}{*}{ STATCOM } & PI & 0.395 & 0.395 & 0.589 & 0.589 & 0.581 & 0.581 & 0.570 & 0.570 \\
\hline & FFPI & 0.180 & 0.180 & 0.190 & 0.190 & 0.182 & 0.182 & 0.176 & 0.176 \\
\hline \multirow{2}{*}{$\begin{array}{l}\text { SC+ } \\
\text { SVC }\end{array}$} & PI & 0.372 & 0.372 & 0.592 & 0.592 & 0.580 & 0.580 & 0.569 & 0.569 \\
\hline & FFPI & 0.176 & 0.176 & 0.192 & 0.192 & 0.183 & 0.183 & 0.186 & 0.186 \\
\hline \multirow{2}{*}{$\begin{array}{l}\text { SC+ } \\
\text { STATCOM }\end{array}$} & PI & 0.354 & 0.354 & 0.568 & 0.568 & 0.556 & 0.556 & 0.545 & 0.545 \\
\hline & FFPI & 0.156 & 0.156 & 0.168 & 0.168 & 0.160 & 0.160 & 0.164 & 0.164 \\
\hline \multirow{2}{*}{$\begin{array}{l}\text { SVC+ } \\
\text { STATCOM }\end{array}$} & PI & 0.367 & 0.367 & 0.585 & 0.585 & 0.572 & 0.572 & 0.560 & 0.560 \\
\hline & FFPI & 0.170 & 0.170 & 0.187 & 0.187 & 0.178 & 0.178 & 0.180 & 0.180 \\
\hline
\end{tabular}

From the inverter DC power recovery simulation results (Fig. 9, 10, 11 and 12 and Table 3, 4), it is observed that in all the cases during rectifier side AC system faults, the system recovery with the firefly algorithm based PI controller is slightly faster than the conventional PI controller. On the other hand, for the faults in the rectifier DC side and inverter AC and DC side, the hybrid RPC's (SC+SVC, SC+ STATCOM and SVC+STATCOM) has reduced fault clearing time than their individual performance (SC, SVC, and STATCOM). In particular, the combination of SC and STATCOM is taking very lesser time to clear the fault among the various RPC's. Further, the firefly algorithm based PI controller makes the system recovery much faster than the conventional PI controller.

\section{CONCLUSION}

In this paper, a detailed performance analysis of hybrid RPC's on the inverter AC sides of MTDC system feeding very weak AC networks was carried out with firefly algorithm based optimal PI controller for rectifiers and inverters control. The various hybrid RPC's considered were $\mathrm{SC}+\mathrm{SVC}$, SC+STATCOM and SVC+STATCOM. This involvement can be very useful for designing and safeguarding persons, for analyzing the interaction between very weak AC networks and MTDC systems under different operating environment. The MTDC transmission system model was executed in the Matlab environment. The transient performances of the hybrid RPC's in an HVDC system were compared with SC, SVC, STATCOM, under various fault condition to examine the suppression of TOV and fault recovery. The simulation results validate that the equal mix of SC+STATCOM has the steady and fastest response and display the superiority of firefly algorithm based PI controller over the conventional fixed gain PI controller. The harmonic analysis outcome also assures the quality of power supply on inverter AC side.

\section{ACKNOWLEDGEMENTS}

The authors gratefully acknowledge the support and facilities provided by the authorities of the Annamalai University, Annamalainagar, Tamilnadu, India to carry out this research work.

\section{REFERENCES}

[1] S. Rüberg, A. L'Abbate, G. Fulli, A. Purvins, "Advanced Technologies for Future Transmission Grids-High-Voltage Direct-Current Transmission", Power Systems, Springer London, 2013, pp. 157-213

[2] J. Reeve, "Multiterminal HVDC Power Systems", IEEE Transaction on Power Apparatus and Systems, vo1. 99, no. 2, 1980, pp. 729-37.

[3] M. Callavik, M. Bahrman, P. Sandeberg, "Technology developments and plans to solve operational challenges facilitating the HVDC offshore grid", Proceedings of Power Energy Society General Meeting, 2012, pp. 1-6.

[4] T. Sakurai, K. Goto, S. Irokawa, K. Imai, T. Sakai, "A New Control Method for Multi-terminal HVDC Transmission without Fast Communication Systems", IEEE Transaction on Power Apparatus and Systems, vol. 102, 1983, pp. 1140-1150.

[5] A. Egea-Alvarez, J. Beerten, D. V. Hertem, O. G. Bellmunt, "Hierarchical power control of Multiterminal HVDC grids" Electric Power Systems Research, vol. 121, 2015, pp. 207-215.

[6] V. K. Sood, "HVDC and FACTS Controllers, Applications of Static Converters in Power Systems", Kluwer Academic Publishers, Boston, MA, 2004.

[7] A. Gavrilovic, 1991, "AC/DC System Strength as Indicated by Short Circuit Ratios", IEEE International Conference on AC-DC Power Transmission, pp. 27-32. 
[8] S. Rao, 2003, EHV-AC HVDC Transmission and Distribution Engineering, Khanna publishers, New Delhi, India.

[9] O. B. Nayak, A. N. Gole, "Dynamic Performance of Static and Synchronous Compensators at an HVDC Inverter Bus in a Very Weak AC System", IEEE Transactions on Power Delivery, vol. 9, no. 3, 1994, pp. $1350-1358$.

[10] C. Weindl, G. Herold, D. Retzmann, H. A. Cardona, I .A. Isaac, G. J. Lopez, 2006, "Feasibility of HVDC for Very Weak AC Systems with SCR below 1.5", IEEE International Conference on Power Electronics and Motion Control, pp. 1522-1527.

[11] Y. Zhuang, R. W. Menzies, 1996, "Dynamic Performance of a STATCON at the HVDC Inverter Feeding a Very Weak AC System", IEEE Transactions on Power Delivery, vol. 11, no. 2, pp. 958-964.

[12] S. Seenivasan, S. Singaravelu, "Analysis of a Monopolar HVDC Transmission System Feeding a Very Weak AC Network with Hybrid Reactive Power Compensators and Firefly Algorithm Based Optimal PI Controller", International Journal of Applied Engineering Research, vol. 9, no. 21, 2014, pp. 10841-10855.

[13] A. Routray, P. K. Dash, S. K. Panda, "A Fuzzy SelfTuning PI Controller for HVDC Links", IEEE Transactions on Power Electronics, vol. 11, no. 5, 1996, pp. 699-679.

[14] P. K. Dash, A. Routary, S. Mishra, "A Neural Network based Feedback Linearising Controller for HVDC Links", Electrical Power Systems Research, vol. 50, no. 2, 1999, pp. 125-132.

[15] N. Bawane, A. G. Kothari, D. P. Kothari, "ANFIS Based HVDC Control and Fault Identification of HVDC converter", HAIT Journal of Science and Engineering, vol. 2, no. 5-6, 2005, pp. 673-689.

[16] X. Zhou, C. Chen, Fan Yang, M. Chen, "Optimization Design of Proportional-Integral Controllers in High-voltage DC System Based on an Improved Particle Swarm Optimization Algorithm", Electric Power Components and Systems, vol. 37, no. 1, 2009, pp. 78-90.

[17] S. Seenivasan, S. Singaravelu, "Modelling and Simulation of Multi-terminal HVDC Transmission System Feeding Strong AC Networks with Firefly Algorithm based Optimal PI Controller", Global Journal of Pure and Applied Mathematics, vol. 11, no. 2, 2015, pp. 579-590.

[18] X. S. Yang, Engineering Optimization: An Introduction to Metaheuristic Applications, Wiley, 2010.

[19] X. S. Yang, "Firefly Algorithms for Multimodal Optimization", Stochastic Algorithms: Foundations and Applications-Springer Berlin Heidelberg, vol. 5792, 2009, pp. 169-178.

[20] X. S. Yang, X. He, "Firefly Algorithm: Recent Advances and Applications", International Journal of Swarm Intelligence, vol. 1, 2013, pp. 36-50.
[21] C. Dufour, J. Mahseredjian, J. Belanger, "A Combined State-Space Nodal Method for the Simulation of Power System Transients", IEEE Transactions on Power Delivery, vol. 26, no. 2, 2011, pp. 928-935.

\section{BIOGRAPHIES}

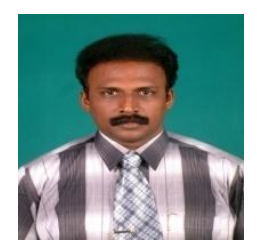

S. Singaravelu received Bachelor of Engineering in Electrical and Electronics in 1990, Master of Engineering in Power System in 1992 and Ph.D. in 2007 from Annamalai University, Annamalai nagar, Tamilnadu, India. At Present, he is a Professor in the Department of Electrical Engineering at Annamalai University. His research interests are in power electronics, power systems, electrical machines, wind/solar energy applications, high voltage DC transmission and smart grids.

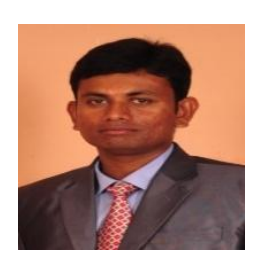

S. Seenivasan received Bachelor of Engineering in Electrical and Electronics in 2005 and Master of Engineering in Power System in 2011 from Annamalai University, Annamalai nagar, Tamilnadu, India. He is currently pursuing Ph.D. degree in the Department of Electrical Engineering, Annamalai University. At present, he is an Assistant Professor in the Department of Electrical Engineering at Annamalai University. His research interests are in high voltage DC transmission systems and soft computing techniques. 